\title{
Analisis Pendapatan Usaha Industri Jamu di Kelompok Tani Prima Mandiri Desa Usapinonot
}

\author{
Maria Elftrida Sako a, dan Adeline Norawati Hutapea ${ }^{b}$ \\ ${ }^{a}$ Fakultas Pertanian, Universitas Timor, Kefamenanu, TTU - NTT, Indonesia. \\ ${ }^{b}$ Fakultas Pertanian, Universitas Timor, Kefamenanu, TTU - NTT, Indonesia.
}

\section{Article Info}

Article history:

Received 11 Mei 2016

Received in revised form 20 Juni 2016

Accepted 16 Juli 2016

\section{Keywords:}

Analisis Pendapatan

Usaha Industri Jamu

Prima Mandiri

Usapinonot

\begin{abstract}
Abstrak
Penelitian ini dilakukan di Kecamatan Insana Barat Kabupaten Timor Tengah Utara, tujuan penelitian ini untuk mengetahui pendapatan usaha industri jamu di Kelompok Tani Prima Mandiri, dan untuk mengetahui keuntungan relatif usaha industri jamu di Kelompok Tan Mandiri. Metode pengambilan data dilakukan secara survei dengan jenis data berupa data primer dan data sekunder. Analisis data dilakukan dengan menggunakan analisis deskriptif, analisis pendapatan dan analisis R/C ratio. Hasil penelitian ini menunjukkan beberapa kesimpulan yakni, penerimaan untuk keseluruhan responden dalam empat kali produksi (1 bulan) adalah sebesar Rp. 44.000 .000 dengan rata-rata pe responden adalah sebesar Rp. 4.000.000. Total biaya produksi untuk keseluruhan responden dalam empat kali produksi (bulan) adalah sebesar Rp. 18.329.500 dengan rata-rata Rp. 1.666.318 per responden. Total pendapatan usaha industri jamu untuk keseluruhan responden dalam satu kali produksi adalah sebesar Rp. 4.776.500 dengan rata-rata Rp. 434.277, sedangkan total pendapatan untuk keseluruhan responden dalam empat kali produksi (bulan) adalah sebesar Rp. 19.248.000 dengan rata-rata per responden adalah sebesar Rp.1.749.818. hal ini menunjukkan bahwa penerimaan, biaya produksi dan pendapatan sangat bervariasi. Nilai rata-rata R/C ratio dari usaha industri jamu adalah sebesar 1,9 sehingga usaha industri jamu tersebut secara ekonomis menguntungkan dan dapat dilanjutkan.. (O2016 dipublikasikan oleh Agrimor.
\end{abstract}

\section{Pendahuluan}

Sektor pertanian mempunyai peranan penting yang sangat besar dalam pertumbuhan ekonomi negara, terutama negara yang bercorak agraris sepert Indonesia. Pembangunan ekonomi menitikberatkan pada bidang pertanian dan industri yang berbasis pertanian atau biasa disebut usaha industri. Dalam sistem agribisnis, usaha industri adalah salah satu subsistem yang bersama-sama dengan subsistem yang lain, membentuk agribisnis. Pembangunan pertanian merupakan seluruh upaya untuk memanfaatkan kekayaan sumber daya alam secara lestar dan berkelanjutan, sumber daya manusia, modal serta ilmu pengetahuan dan teknologi dalam penghasilan

Permintaan komoditas pertanian cenderung menurun, karena komoditas pertanian tidak tahan lama apabila disimpan dalam jangka waktu yang panjang Sehingga kelompok tani prima mandiri melakukan usaha industri yaitu mengolah bahan baku menjadi produk olahan yang baru, dan mendapatkan harganya relatif lebih tinggi bahkan lebih stabil. Oleh sebab itu agroindustri perlu dikembangkan karena mampu meningkatkan nilai tambah, dan meningkatkan pendapatan produsen (Soekartawi, 1994). Permasalahan yang terjadi sekarang ini adalah rendahnya kemampuan masyarakat dalam memanfaatkan sumber daya yang ada dan menangkap peluang bisnis yang bisa meningkatkan pendapatannya.

Kelompok tani prima mandiri di Desa Usapinonot Kecamatan Insana Barat merupakan salah satu kelompok yang dibentuk sejak tahun 2006 dengan jumlah anggota sebanyak 11 orang. Menurut Mardikanto (1993) kelompok tani dapa diartikan sebagai kumpulan orang-orang tani atau yang terdiri dari petani dewasa (pria/wanita) maupun petani teruna (pemuda/pemudi) yang terikat secara forma dalam suatu wilayah keluarga atas dasar keserasian dan kebutuhan bersama serta berada di lingkungan pengaruh dan pimpinan seorang kontak tani. Kontak tan adalah ketua kelompok tanin yang dipilih dari anggota dan oleh anggota kelompok berdasarkan musyawarah

Jamu merupakan salah satu bentuk olahan yang dibuat dari bahan-bahan alami, berupa bagian dari tumbuhan seperti rimpang (akar-akar), daun-daunan, kulit batang, dan buah. Jamu juga merupakan obat tradisional Indonesia yang dipakai sejak dahulu dan sudah terbukti khasiatnya. Penggunaan jamu di Indonesia didukung oleh potensi alam negeri ini yang kaya akan keanekaragaman tanaman obat. Jenis jamu yang diproduksi di kelompok Tan Prima Mandiri meliputi jamu temulawak, Jamu mengkudu, jamu kunyit putih, jamu jahe dan jamu sirsak. Pengertian jamu dalam Permenkes No 003/MENKES/PER/I/2010 adalah bahan atau ramuan bahan yang berupa tumbuhan, bahan hewan, bahan mineral, sediaan serian (generik), atau campuran dari bahan tersebut yang secara turun temurun telah digunakan untuk pengobatan berdasarkan pengalaman dan dapat diterapkan sesuai norma yang berlaku d masyarakat (Departemen Kesehatan, 2010).

Data produksi beberapa jenis jamu di kelompok tani Prima Mandiri pada lima tahun terakhir yakni pada tahun 2011 produksi dari lima jenis jamu tersebu sebanyak 5.500 bungkus, pada tahun 2012 sebanyak 3.500 bungkus, pada tahun 2013 sebanyak 4.500 bungkus, dan 2014 sebanyak 6.000 bungkus. Berdasarkan data tersebut dapat di simpulkan bahwa dari tahun ke tahun usaha industri in selalu mengalami peningkatan. Dari data produksi tersebut penulis ingin menelit tentang usaha industri jamu karena dalam pengembangan usaha industri jamu, ada beberapa kendala yang dihadapi oleh kelompok tani Prima Mandiri khususnya dalam meningkatkan pendapatan yakni kurangnya perhitungan terhadap perkembangan usaha yang dilakukan apakah menguntungkan atau merugikan.

Berdasarkan latar belakang yang ada maka dilakukan penelitian tentang analisis pendapatan usaha industri jamu di kelompok tani Prima Mandiri desa Usapinonot dengan tujuan untuk mengetahui 1) gambaran usaha industri jamu 2) pendapatan usaha industri jamu; dan 3) keuntungan relatif usaha industri jamu di kelompok tani Prima Mandiri Desa Usapinonot Kecamatan Insana Barat.

\section{Metode}

Penelitian ini dilaksanakan pada bulan Februari sampai April 2016 di Kelompok tani Prima Mandiri di Desa Usapinonot Kecamatan Insana Bara Kabupaten Timor Tengah Utara (TTU). Pengumpulan data akan dilakukan dengan metode survey, dimana data yang digunakan berupa data primer dan data sekunder. Data primer adalah data-data yang diperoleh melalui wawancara dengan responden berdasarkan daftar pertanyaan yang disiapkan sebelumnya Sedangkan data sekunder adalah data yang diperoleh dari instansi-instansi terkait.

Metode penentuan sampel dalam penelitian ini dilakukan secara sensus yaitu keseluruhan anggota kelompok tani dijadikan sebagai responden yang berjumlah 11 responden dengan alasan bahwa semua anggota kelompok ini mengusahakan jamu, dan juga usaha industri jamu adalah satu-satunya usaha yang dikembangkan di Desa Usapinonot Kecamatan Insana Barat.

Pengamatan dan konsep pengukuran yang dilakukan dalam penelitian ini adalah identitas responden, gambaran umum kelompok tani, kegiatan usaha industri jamu meliputi pengolahan mengkudu dan temulawak, produksi yakni jumlah output jamu yang diperoleh, input, jumlah curahan kerja, pengalaman, jumlah anggota, biaya tetap (Fixed cost), biaya variabel (variable cost), penerimaan dan pendapatan.

Analisis yang digunakan adalah analisis deskriptif kualitatif yang merupakan analisis yang berguna untuk menggambarkan variabel yang diteliti. Pendapatan, penerimaan dan keuntungan relatif dihitung sesuai dengan petunjuk Sugiyono, (2006).

\section{Hasil dan Pembahasan}

\subsection{Gambaran Umum Cara Pembuatan Jamu}

Menurut hasil penelitian yang diperoleh bahwa cara pembuatan dari kelima jenis jamu ini pada dasarnya sama, yakni mula-mula menyiapkan alat dan bahan yang dibutuhkan untuk melancarkan proses pembuatan jamu tersebut hanya beda pada takaran atau banyaknya jenis bahan baku yang mau dibutuhkan dalam proses pembuatan jamu tersebut. Berikut ini adalah cara pembuatan jamu.

a. Penyortiran

Bahan-bahan baku yang dibutuhkan seperti mengkudu, temulawak, kunyit putih, jahe dan sirsak diambil kemudian dipilih yang baik untuk digunakan sebagai bahan baku pembuatan jamu.

b. Pencucian atau pembersihan

Bahan-bahan baku yang sudah dipilih sebagai bahan dasar pembuatan jamu kemudian dicuci di dalam ember menggunakan air bersih. Untuk temulawak, kunyit putih, dan jahe dibersihkan kulitnya menggunakan sikat gigi yang bersih, bisa juga menggunakan pisau.

c. Peremasan

Khusus buah mengkudu di remas- remas menggunakan air panas untuk memisahkan antara daging mengkudu dan bijinya, dan untuk buah sirsak dibersihkan menggunakan sendok makan atau garpu untuk memisahkan antara daging sirsak dan bijinya.

d. Penggilingan

Daging buah mengkudu, buah sirsak, temulawak, kunyit putih dan jahe yang sudah dibersihkan kemudian dimasukkan ke dalam penggiling, untuk melakukan penggilingan sampai halus. Ketika sudah halus maka langkah selanjutnya adalah melakukan penyaringan.

e. Penyaringan

Penyaringan dilakukan dengan maksud agar bahan baku yang telah dihaluskan dapat disaring menggunakan saringan atau serbet sehingga dapat memisahkan ekstrak dari ampas bahan baku tersebu.

f. Pemasakan

Untuk proses pemasakan semua jenis jamu pada dasarnya sama yakni ekstrak atau sari yang telah dipisahkan dari ampasnya kemudian dituangkan ke dalam wajan, masukkan gula pasir, kayu manis dan bunga cengkeh dan mulailah memasak menggunakan api sedang. 


\section{g. Pengadukan}

Sari atau ekstrak dari setiap bahan baku yang telah dituangkan ke dalam wajan kemudian diaduk perlahan-lahan, ketika sudah mendekat matang akan terasa lengket dan berat, maka lakukanlah pengadukan yang lebih cepat dan terus menerus sehingga jamu tidak gosong.

h. Penghalusan

Jamu yang sudah matang akan berbentuk kristal maka dapat dikeluarkan ke dalam nyiru, untuk kemudian dilakukan penghalusan dengan menggunakan salah satu alat seperti setrika kayu agar memudahkan untuk menghaluskan jamu yang mengkristal atau menggumpal, kemudian biarkan kurang lebih 20 menit untuk jamu tersebut betul-betul dingin untuk kemudian dilakukan pengemasan.

i. Pengemasan

Jamu yang sudah didinginkan kemudian ditimbang, dan dikemas ke dalam plastik kemasan yang sudah diberi label sebelumnya, dan sudah tercantum tanggal kadaluwarsanya. Kemasan yang digunakan rata-rata berukuran 500 gram, kemasan ini digunakan untuk mengemas semua jenis jamu yang siap dipasarkan. Jamu ini, bertahan lima sampai enam bulan.

j. Pemasaran jamu

Pemasaran merupakan tahap terakhir dari usaha industri jamu. Berdasarkan hasil wawancara pemasaran dari hasil produksi jamu ini, dilakukan di Kabupaten Timor Tengah Utara yakni, di toko-toko terdekat seperti di Toko Apotek Central, Toko Lay, Apotek Surya Farma, Toko Tulip, Happy Swalayan, Deperindakop, dan sebagian dijual dengan berjalan keliling. Sedangkan luar kabupaten, seperti di TTS, Kupang, Flores, Rote, dan Atambua di pasarkan dengan cara di dilayani sendiri pada saat pameran. Sedangkan pemasaran yang dilakukan di Medan, Irian jaya, Jawa, dan negara Republic Democratica Timor Leste biasanya di pasarkan dengan cara pemesanan dari para Biarawan dan Biarawati, dengan diambil langsung yang mana di tempat atau lokasi produksi. Harga produk yang berlaku di lokasi pemasaran semuanya sama yakni Rp 25.000/ bungkus. Penentuan harga produk dilakukan atas dasar kesepakatan bersama yang mana sudah dihitung biaya produk secara komprehensif atau secara menyeluruh.

\subsection{Jenis- Jenis Jamu yang Diusahakan}

\section{○ Jamu mengkudu}

Jamu mengkudu, merupakan jenis jamu yang terbuat dari sari atau ekstrak buah mengkudu dan gula pasir, dengan takarannya yaitu $1 \mathrm{~kg}$ gula pasir berbanding 25 buah mengkudu.

- Jamu temulawak

Jamu temulawak merupakan jenis jamu yang dibuat dari bahan dasar temulawak, gula pasir, kayu manis, dan cengkeh. Takaran dalam membuat jamu temulawak yaitu 1 kilo gram temulawak berbanding 1 kilo gram gula pasir, dan tambahkan juga dengan bunga cengkeh dan kayu manis secukupnya.

- Jamu kunyit putih

Jamu kunyit putih merupakan jenis jamu yang dibuat dari bahan dasar sari atau ekstrak kunyit putih, gula pasir, dan bahan tambahan lainnya seperti kayu manis, dan bunga cengkeh. Takaran untuk membuat jamu kunyit putih yaitu $1 \mathrm{~kg}$ kunyit putih berbanding $1 \mathrm{~kg}$ gula pasir.

- Jamu jahe

Jamu jahe merupakan jenis jamu yang dibuat dari ekstrak jahe, dan gula pasir. Takaran untuk membuat jamu jahe yaitu $1 \mathrm{~kg}$ jahe berbanding $1 \mathrm{~kg}$ gula pasir, dan ditambahkan kayu manis dan bunga cengkeh secukupnya. Jamu jahe ini sangatlah baik untuk kesehatan tubuh.

- Sirsak

Jamu sirsak merupakan jenis jamu yang dibuat dari buah sirsak dan ekstrak daun sirsak dan ditambahkan dengan gula pasir, namun apabila buah sirsak tidak ada atau bukan pada musim buah sirsak maka jamu sirsak bisa saja dibuat dengan menggunakan ekstrak dari daun sirsak.

\subsection{Gambaran Penggunaan Modal}

Modal merupakan rangkaian biaya yang dikeluarkan oleh setiap responden untuk membeli bahan dan alat yang dibutuhkan dalam proses pembuatan jamu. Modal awal yang digunakan oleh anggota kelompok tani Prima Mandiri yaitu menggunakan modal sendiri atau swadaya dari masing-masing anggota kelompok Rp 50.000 dan mendapatkan modal dari pemerintah berupa bantuan alat-alat seperti siler 11 unit, mesin pres 1 unit, satu unit meteran listrik satu buah gedung dengan ukuran $6 \times 7 \mathrm{~m}$, timbangan 11 unit, sehingga sampai saat in anggota kelompok tani prima mandiri belum pernah menggunakan modal dari pihak bank atau koperasi, dengan pertimbangan bahwa risiko yang besar jika menggunakan modal dari bank atau koperasi. Berikut ini merupakan uraian tentang biaya produksi yang terdiri dari biaya variabel dan biaya tetap.

- Biaya variabel

Biaya variabel merupakan biaya yang digunakan untuk pengadaan bahan baku (mengkudu, temulawak, kunyit putih, jahe dan sirsak), yang mana $1 \mathrm{~kg}$ mengkudu adalah sebesar Rp. 2000, dan 1 kg temulawak, kunyit putih, jahe dan sirsak adalah sebesar Rp. 5000. bahan penolong, (bahan bakar, kemasan), biaya listrik dan biaya transportasi. Sedangkan biaya tenaga kerja tidak diperhitungkan atau tidak diupah, karena rata-rata para anggota kelompok tani prima mandir menggunakan tenaga kerja dalam keluarga. Berdasarkan hasil penelitian bahwa asal bahan baku yang digunakan pada Kelompok Tani Prima Mandiri seluruhnya diperoleh dengan cara mengambil di kebun masing-masing, namun jika terjadi kekurangan bahan baku para anggota Kelompok membeli bahan baku. Rata-rata penggunaan bahan baku dalam setiap kali produksi adalah sebesar $7 \mathrm{~kg}$ buah mengkudu, $5 \mathrm{~kg}$ temulawak, $3 \mathrm{~kg}$ kunyit putih, $3 \mathrm{~kg}$ jahe, $2 \mathrm{~kg}$ sirsak. Gula pasir rata-rata penggunaannya dapat disesuaikan dengan banyaknya jenis bahan baku yang disediakan yakni $20 \mathrm{~kg}$, dan bahan baku tambahan lainnya seperti kayu manis dan bunga cengkeh 1 ons, namun untuk bahan baku tambahan ini bisa digunakan untuk beberapa kali produksi.

- Biaya tetap

Biaya tetap meliputi biaya penyusutan peralatan seperti wajan, sutel, baskom, dan pisau. Sedangkan alat lain seperti serbet, gayung, saringan, ember, dan nyiru tidak memiliki biaya penyusutan yang mana ketika alat-alat tersebut mengalami kerusakan maka langsung dibuang.

\subsection{Penerimaan}

Penerimaan yang diperoleh responden dapat di hitung dari total produksi di kalikan dengan harga jual jamu perkemasan, harga jual jamu perkemasan senilai Rp. 25.000. Total produksi jamu per responden dalam satu kali produksi adalah sebanyak 40 kemasan, sedangkan total produksi jamu per responden dalam satu bulan adalah sebanyak 160 kemasan.

\subsection{Pendapatan}

Pendapatan yang diperoleh responden dapat di hitung dari total penerimaan di kurangi dengan total biaya produksi. Berdasarkan hasil tabulasi data tersebut maka total pendapatan untuk keseluruhan responden dalam satu kali produksi (1 minggu) sebesar Rp. 5.271.500 dengan rata-rata per responden adalah sebesar Rp. 497.227, sedangkan pendapatan untuk keseluruhan responden dalam empat kali produksi (bulan) adalah sebesar Rp. 21.228.000 dengan rata-rata per responden adalah sebesar Rp. 1.929.818.

\subsection{Analisis Keuntungan Relatif usaha industri jamu}

Keuntungan relatif secara ekonomis pada daerah penelitian dapat ditentukan dengan menghitung $\mathrm{R} / \mathrm{C}$ ratio (Retrun Cost Ratio) yaitu perbandingan antara total penerimaan usaha industri jamu dengan total biaya yang telah dikeluarkan. Berdasarkan hasil penelitian menunjukkan bahwa nilai rata-rata $\mathrm{R} / \mathrm{C}$ ratio sebesar 1,9 maka dapat disimpulkan bahwa usaha industri jamu di kelompok tan prima mandiri Desa Usapinonot Kecamatan Insana Barat Kabupaten Timor Tengah Utara menguntungkan secara ekonomis. Hal ini sesuai dengan hasi penelitian Anita Andriany tentang analisis pendapatan usaha pembuatan minuman sari jahe yang mana nilai R/C Rationya adalah 1,27 artinya dengan memiliki nilai ratio tersebut maka setiap Rp. 100.000 yang dikeluarkan akan memperoleh manfaat sebesar Rp. 127.000, dengan demikian usaha pembuatan minuman sari jahe secara keseluruhan menguntungkan dan layak untuk dijalankan.

\section{Simpulan}

Berdasarkan hasil penelitian pendapatan usaha industri jamu untuk keseluruhan responden adalah sebesar Rp.5.277.500, dengan rata-rata per responden adalah sebesar Rp. 479.773 dalam satu kali produksi (minggu) Sedangkan pendapatan untuk keseluruhan responden dalam empat kali produks (bulan) adalah sebesar Rp. 21.252.000 dengan rata-rata 1,932.000 per responden. Nilai R/C ratio usaha industri jamu di kelompok tani Prima Mandiri diperoleh dari perbandingan antara total penerimaan usaha industri jamu dengan total biaya produksi yang dikeluarkan, yang mana total penerimaan untuk keseluruhan responden dalam satu kali produksi (minggu) adalah sebesar Rp. 11.000.000 dengan rata-rata per responden Rp. 1.000.000, dan total penerimaan untuk keseluruhan responden dalam empat kali produksi (bulan) adalah sebesar $\mathrm{Rp}$. 44.000.000 dengan rata-rata per responden adalah sebesar Rp. 4.000.000. Total biaya produksi untuk keseluruhan responden dalam satu kali produksi adalah sebesar Rp. 5.722.500 dengan rata-rata per responden adalah sebesar Rp. 520.227. Sedangkan total biaya produksi untuk keseluruhan responden adalah sebesar Rp. 18.329.500 dengan rata-rata per responden sebesar Rp. 1.666.318 Hal ini menunjukkan bahwa nilai $\mathrm{R} / \mathrm{C}$ rationya lebih besar dari 1, artinya bahwa usaha industri jamu di kelompok tani Prima Mandiri menuntungkan sehingga bisa dapat dilanjutkan.

\section{Pustaka}

Departemen Kesehatan RI, 2010. Peraturan Menteri Kesehatan Nomor 003/MENKES/PER/I/2010 Tahun 2010 Tentang Saintifikasi Jamu Dalam Penelitian Berbasis Pelayanan Kesehatan.

Mardikanto, T. 1993. Penyuluhan Pembangunan Pertanian. Surakarta: Sebelas Maret University Press.

Soekartawi. 1994. Agribisnis Teori dan Aplikasinya. Jakarta: CV Rajawali.

Sugiyono. 2006. Metode Penelitian Kuantitatif, Kualitatif dan $R \&$ D. Bandung: Alfabeta. 